\title{
Dampak Investasi, Proyek dan Utang Luar Negeri Terhadap Kemiskinan Indonesia Tahun 2010-2020
}

\author{
Anas Fadhillah, Arintoko, Kamio \\ Faculty of Economics and Business, Universitas Jenderal Soedirman, Indonesia \\ Correspondence email: anasfadhillah.AF@gmail.com
}

\begin{abstract}
Abstrak. Tujuan dari penelitian ini menganalisis percepatan pengentasan kemiskinan melalui investasi, proyek, dan utang luar negeri dari negara Amerika, Belanda, China dan Jepang Terhadap Kemiskinan Indonesia Tahun 2010-2020. Teknik yang digunakan dalam penelitian ini menggunakan regresi data panel. Data yang digunakan dalam penelitian ini variabel terikat kemiskinan, variabel bebas investasi, proyek, utang luar negeri. Data analisis diambil dari Badan Pusat Statistik tahun 2010-2020. Berdasarkan Uji Chow dan Uji Hausman analisis ini terpilih adalah Fixed Effect Model dan telah lulus uji asumsi klasik. Hasil menunjukkan bahwa investasi dan proyek berpengaruh negatif signifikan terhadap kemiskinan dan utang luar negeri tidak signifikan berpengaruh terhadap kemiskinan, yang artinya investasi, dan proyek, mengurangi kemiskinan di Indonesia. Berdasarkan hasil penelitian ini, maka implikasi penelitian ini adalah pemerintah pusat, pemerintah daerah, Bank Indonesia dan lembaga terkait meningkatkan investasi dan proyek luar negeri dengan menjalin hubungan yang baik dengan negara sahabat, mempermudah perizinan investasi di Indonesia, mengelola utang luar negeri dengan baik dengan memprioritaskan pertumbuhkan ekonomi dan pengentasan kemiskinan.
\end{abstract}

Kata Kunci: Data Panel, Investasi, Kemiskinan, Proyek, dan Utang Luar Negeri

Abstract. The purpose of this study is to analyze the acceleration of poverty alleviation through investment, projects, and foreign debt from the United States, the Netherlands, China and Japan on Indonesian Poverty in 2010-2020. The technique used in the study used panel data regression. The data used in the study of poverty variables, investment variables, projects, foreign debt. Data analysis was taken from the Central Statistics Agency in 2010-2020. Based on the Chow Test and the Hausman Test, this analysis was chosen to be the Fixed Effect Model and has passed the assumptions of the classical test. The results show that investment and projects have a significant negative effect on poverty and foreign debt has no significant effect on society, which means investment, projects, poverty in Indonesia. Based on the results of this study, the implications of this study are that the central government, local governments, Bank Indonesia and related institutions increase investment and foreign projects by establishing good relations with friendly countries, facilitating investment licensing in Indonesia, good foreign debt by prioritizing growth. Economy and poverty alleviation.

Keywords: Panel Data, Investment, Poverty, Projects, and External Debt

\section{PENDAHULUAN}

Semua negara di dunia berupaya untuk mengentaskan kemiskinan, Republik Indonesia salah satu negara yang fokus terhadap pengentasan kemiskinan, kemiskinan merupakan permasalah yang serius untuk diatas oleh pemerintah. Masalah kemiskinan yang begitu kompleks berkaitan dengan aspek sosial dan budaya, ekonomi dan lainya. Aspek sosial dan budaya kemiskinan mengakibatkan derajat sosialnya rendah, orang miskin dianggap remeh oleh orang lain dan cenderung berperilaku kriminal. Pada aspek ekonomi masyarakat miskin tidak mempunyai pendapatan tinggi, kemiskinan juga membuat masyarakat tidak dapat memenuhi kebutuhan barang dan jasa.

Kemiskinan di Indonesia masih tergolong tinggi, berdasarkan data Badan Pusat Statistik kemiskinan pada tahun 2018 jumlah penduduk miskin sebesar 25,67 juta dan pada tahun 2019 jumlah penduduk miskin sebesar 24,74 juta. Penduduk miskin masih banyak ditemukan pada perdesaan, tahun 2018 penduduk miskin di pedesaan sebesar 15,54 juta penduduk dan pada tahun 2019 penduduk miskin sebesar 14,43 juta penduduk. Penyebab penduduk miskin di pedesaan karena tingkat pendidikan rendah, keterbatasan keterampilan, terbatasnya lapangan pekerjaan di pedesaan dan rendahnya modal. Pada perkotaan juga masih terdapat kemiskinan, jumlah penduduk miskin di perkotaan tahun 2018 sebesar 10,13 juta dan pada tahun 2019 sebesar 9,86 juta penduduk, penyebab kemiskinan di perkotaan yaitu perpindahan penduduk pedasaan ke perkotaan tanpa keterampilan sehingga diperkotaan menjadi pengangguran atau berpendapatan rendah, tidak memiliki modal, dan pendidikan rendah. Data tersebut menunjukan bahwa masih penting penelitan tentang upaya pengentasan kemiskinan Indonesia.

Tabel 1. Indeks Keparahan dan Kedalaman Kemiskinan Menurut Provinsi (Persen) 2015-2019

\begin{tabular}{rcc}
\hline \multirow{2}{*}{ Tahun } & \multicolumn{2}{c}{ Indeks } \\
\cline { 2 - 3 } & Keparahan Kemiskinan & $\begin{array}{l}\text { Kedalaman } \\
\text { Kemiskian }\end{array}$ \\
\hline 2015 & 0.51 & 1.84 \\
2016 & 0.44 & 1.74 \\
2017 & 0.46 & 1.79 \\
2018 & 0.41 & 1.63 \\
2019 & 0.36 & 1.50 \\
\hline
\end{tabular}

Sumber: Badan Pusat Statistik 
Indeks keparahan kemiskinan merupakan gambaran yang memberikan penyebaran pengeluaran diantara penduduk miskin, jika semakin tinggi nilai indeks maka semakin tinggi ketimpangan pengeluaran diantara penduduk miskin. Sedangkan indeks kedalaman kemiskinan merupakan rata-rata kesenjangan pengeluaran tiap-tiap penduduk miskin terhadp garis kemiskinan. Berdasarkan Tabel 1.2 indeks keparahan kemiskinan di Indonesia mengalami penurunan dari tahun ke tahun, akan tetapi tingkat keparahan kemiskinan masih tinggi, begitu juga dengan angka kedalam kemiskinan di Indonesia mengalami fluktuasi tiap tahunya, akan tetapi kedalaman kemiskinan masih tinggi.

Penanganan kemiskinan membutuhkan dana yang cukup besar, salah satu alternatif pendanaan penanganan kemiskinan adalah investasi. Menurut penelitian Tarigan (2021) menyebutkan investasi berpengaruh negatif terhadap kemiskinan, artinya semakin meningkatnya investasi akan mengakibatkan menurunya penduduk miskin, berbeda dengan penelitian Sutikno et al (2019) meyebutkan investasi pemerintah tidak memberikan dampak yang signifikan, dan secara slimutan variabel upah minimum dan investasi secara bersama memberikan pengaruh yang positif terhadap kemiskinan. Sedangkan pada penelitian Pratama et.al (2017) investasi memberikan pengaruh yang signifikan terhadap pertumbuhan ekonomi begitu juga dengan tenaga kerja yang memberikan pengaruh yang signifikan terhadap pertumbuhan ekonomi, Tingkat Pendidikan juga memberikan pengaruh yang signifikan terhadap pertumbuhan ekonomi. Sedangkan investasi memberikan pengaruh tidak langsung yang signifikan terhadap kemiskinan melalui pertumbuhan ekonomi di Sulawesi Utara, akan tetapi tenaga kerja secara tidak langsung belum bisa memberikan pengaruh yang signifikan terhadap kemiskinan melalui pertumbuhan ekonomi. Tingkat Pendidikan memberikan pengaruh yang signifikan terhadap kemiskinan. Metode yang digunakan dalam penelitian ini adalah Analisis Path. Pada penelitian ini menggunakan data terbaru tahun 2010-2020, sehingga dapat menarik kesimpulan yang tepat dan pengambilan kebijakan yang tepat pada kondisi terkini. Data yang digunakan merupakan data panel yang berbeda dengan penelitian sebelumnya kebanyakan menggunakan data time series. Kontribusi lain pada penelitian ini memberikan analisis dampak investasi, proyek, dan utang luar negeri terhadap kemiskinan dan pengembangan penelitian terdahulu untuk mengatasi tingkat kemiskinan.

\section{Landasan Teori \\ Kemiskinan}

Kemiskinan memiliki arti dari berbagai aspek, seseorang dikategorikan sebagai miskin bisa tergantung dimana dia tinggal, kondisi tertentu, dan pendapatan tertentu. Seseorang yang memiliki pendapatan tertentu dapat dikatakan miskin ketika masyarakat disekitar memiliki pendapatan yang lebih banyak.. Kemiskinan telah mengalami perluasan, seiring dengan berkembangnya faktor penyebab kemiskinan itu sendiri. Kemiskinan tidak lagi hanya dianggap sebagai dimensi ekonomi, tapi telah meluas ke dimensi lainnya. Kemiskinan dapat dilihat dari berbagai segi, baik dari pendapatan, pendidikan, kesehatan, ketenagakerjaan, laju pertumbuhan ekonomi,investasi, inflasi, ketahanan pangan, pembangunan infrastruktur sosial ekonomi wilayah (PISEW), tenaga kerja, perkembangan usaha ekonomi kerakyatan, ketimpangan struktur usaha, ketidakberdayaan, kesejahteraan sosial, ketimpangan gender, kesenjangan antar golongan dan wilayah, pembangunan sumber daya manusia Pratama (2017).

Menurut Bank Dunia, kemiskinan merupakan ketidakmampuan seseorang untuk memenuhi standar hidup yang telah dikategorikan oleh Bank Dunia, standar hidup yang minimal atau kemiskinan dapat juga diartikan mengenai keadaan melarat dan ketidakberuntungan atau suatu keadaan minus (deprivation). Kemiskinan juga berkaitan dengan rendahnya tingkat pendapatan dan kepemilikan harta, kelemahan fisik, isolasi, kerentanaan dan ketidakberdayaan.

Pada dasarnya definisi kemiskinan dapat dibedakan menjadi dari dua sisi, yaitu:

a. Kemiskinan Absolut Kemiskinan yang dikaitkan dengan perkiraan tingkat pendapatan dan kebutuhan yang hanya dibatasi pada kebutuhan pokok atau kebutuhan dasar minimum yang memungkinkan seseorang untuk hidup secara layak. Dengan demikian kemiskinan diukur dengan membandingkan tingkat pendapatan orang dengan tingkat pendapatan yang dibutuhkan untuk memperoleh kebutuhan dasarnya yakni makanan, pakaian dan perumahan agar dapat menjamin kelangsungan hidupnya.

b. Kemiskinan Relatif Kemiskinan dilihat dari aspek ketimpangan sosial, karena ada orang yang sudah dapat memenuhi kebutuhan dasar minimumnya tetapi masih jauh lebih rendah dibanding masyarakat sekitarnya (lingkungannya). Semakin besar ketimpangan antara tingkat penghidupan golongan atas dan golongan bawah maka akan semakin besar pula jumlah penduduk yang dapat dikategorikan miskin, sehingga kemiskinan relatif erat hubungannya dengan masalah distribusi pendapatan. Menurut Todaro dan Smith (2006) menyatakan bahwa variasi kemiskinan dinegara berkembang disebabkan oleh beberapa faktor, yaitu: (1) perbedaan geografis, jumlah penduduk dan tingkat pendapatan, (2) perbedaan sejarah, sebagian dijajah oleh negara yang berlainan, (3) perbedaan kekayaan sumber daya alam dan kualitas sumber daya manusianya, (4) perbedaan peranan sektor swasta dan negara, (5) 
perbedaan struktur industri, (6) perbedaan derajat ketergantungan pada kekuatan ekonomi dan politik negara lain dan (7) perbedaan pembagian kekuasaan, struktur politik dan kelembagaan dalam negeri.

\section{Investasi}

Investasi dapat diartikan sebagai pengeluaran atau perbelanjaan penanam - penanam modal atau perusahaan untuk membeli barang-barang modal dan perlengkapanperlengkapan produksi untuk menambah kemampuan memproduksi barang-barang dan jasa-jasa yang tersedia dalam perekonomian. Investasi bagi suatu perusahaan tidak hanya untuk memaksimalkan output, tetapi untuk meningkatkan profit perusahaan, menambah jumlah tenaga kerja dan distribusi pendapatan, pertumbuhan dan kualitas penduduk, penggunaan teknologi canggih dan mengurangi kemiskinan. Dalam penelitian ini investasi yang digunakan sebagai variabel penelitian adalah investasi dari negara Amerika Serikat, Belanda, China dan Jepang.

Menurut Jhingan (2012: 483), jenis-jenis investasi asing yaitu:

1. Investasi Langsung Perusahaan dari negara penanam modal secara de facto atau de jure melakukan pengawasan atas asset (aktiva) yang ditanam di negara pengimpor modal dengan cara investasi itu. Investasi langsung dapat mengambil beberapa bentuk, yaitu: pembentukan secara cabang perusahaan di negara pengimpor modal; pembentukan suatu perusahaan dalam mana perusahaan di negara penanam modal memiliki mayoritas saham; pembentukan suatu perusahaan di negara pengimpor yang semata-mata dibiayai oleh perusahaan yang terletak di negara penanam modal; mendirikan suatu korporasi di negara penanam modal untuk secara khusus beroperasi di negara lain; atau menaruh asset (aktiva) tetap di negara lain oleh perusahaan nasional dari negara penanam modal.

2. Investasi Tidak Langsung Investasi tidak langsung, lebih dikenal sebagai investasi portofolio atau rentier yang sebagian besar terdiri dari penguasaan atas saham yang dapat dipindahkan (yang dikeluarkan atau dijamin oleh pemerintah negara pengimpor modal), atas saham atau surat utang oleh warga negara dari beberapa negara lain. Penguasaan saham tersebut tidaklah sama dengan hak untuk mengendalikan perusahaan.

\section{Peranan Investasi Dalam Pengentasan Kemiskinan}

Kegiatan investasi memungkinkan suatu masyarakat terus menerus meningkatkan kegiatan ekonomi dan kesempatan kerja, meningkatkan pendapatan nasional dan meningkatkan taraf kemakmuran masyarakat. Peranannya ini bersumber dari tiga fungsi penting dari kegiatan investasi dalam perekonomian.
1. Investasi merupakan salah satu komponen dari pengeluaran agregat. Kenaikan investasi akan meningkatkan permintaan agregat dan pendapatan nasional. Peningkatan seperti ini akan selalu diikuti oleh pertambahan dalam kesempatan kerja, kesempatan kerja meningkat akan menyerap tenaga kerja dan mengurangi pengangguran, masyarakat mendapatkan pendapatan dan kemiskinan akan menurun.

2. Pertambahan barang modal sebagai akibat investasi akan menambah kapasitas memproduksi di masa depan dan perkembangan ini akan menstimulir pertambahan produksi nasional dan kesempatan kerja.

3. Investasi selalu diikuti oleh perkembangan teknologi. Perkembangan ini akan memberi sumbangan penting ke atas kenaikan produktivitas dan pendapatan per kapita masyarakat sehingga masyarakat dapat memenuhi kebutuhan barang dan jasa.

\section{Proyek}

Kegiatan proyek pembangunan merupakan suatu kegiatan sementara yang berlangsung dalam jangka waktu tertentu, dengan alokasi sumber daya tertentu untuk menghasilkan produk yang kriteria mutunya telah disusun dengan jelas, proyek ini diharapkan memberikan keuntungan. Proyek juga dapat diartikan sejenis investasi khusus yang mengacu pada kegunaan, ukuran yang pas, lokasi yang jelas, memperkenalkan sesuatu yang bersifat baru dan adanya harapan bahwa rangkaian pembangunan lebih lanjut dapat dilakukan secara lebih canggih. Pada penelitian ini proyek yang digunakan proyek infrastruktur maupun proyek program kerjasama antara Indonesia dengan Amerika, Belanda, Jepang dan China.

\section{Hubungan Antara Proyek Pembangunan dengan Kemiskinan}

Pemerintah terus melakukan pembangunan, pembangunan ini membutuhkan dana yang besar, pemerintah membutuhkan pengeluaran pembangunan dari anggaran penerimaan dan belanja negara (APBN). Besarnya APBN yang lebih kecil dibanding dengan rencana kegiatan pembangunan menyebabkan kegiatan pelaksanaan pembangunan tidak berjalan sesuai rencana. Kesenjangan antara penerimaan negara dan program pemerintah tersebut selanjutnya dapat ditutup dengan masuknya dana dari luar negeri. Salah satu alternatif pembiayaan tersebut adalah melalui proyek kerjasama dengan negara lain. Proyek pembangunan juga berperan dalam mengatasi kemiskinan. Hal ini terjadi karena proyek kerjasama memberikan tambahan devisa yang diperlukan untuk membiyai program kemiskinan seperti pembangunan saran dan prasaran infrastruktur. 


\section{Utang Luar Negeri}

Utang luar negeri adalah setiap pembiayaan pembangunan yang dikembalikan dengan bunganya, melalui utang yang diperoleh pemerintah dari pemberian pinjaman luar negeri yang diikat oleh suatu perjanjian pinjaman dan tidak berbentuk surat berharga negara, yang harus dibayar kembali dengan persyaratan tertentu (Shopia, 2018). Todaro (2011) mengatakan, bantuan luar negeri adalah seluruh pinjaman serta hibah konsensional resmi, baik dalam bentuk uang tunai maupun bentuk aktiva-aktiva lainnya, yang secara umum ditunjukkan untuk mengalihkan sejumlah sumber daya dari negara maju ke negara berkembang.

Dari aspek materiil, utang luar negeri merupakan arus masuk modal dari luar ke dalam negeri yang dapat menambah modal yang ada di dalam negeri. Aspek formal mengartikan utang luar negeri sebagai penerimaan atau pemberian yang dapat digunakan untuk meningkatkan investasi guna menunjang pertumbuhan ekonomi, ekonomi terus tumbuh akan secara otomatis meningkatkan tenaga kerja dan menyerap pengangguran masyarakat mendapatkan pendapatan dan tidak menganggur lagi. Sehingga berdasarkan aspek fungsinya, pinjaman luar negeri merupakan salah satu alternatif sumber pembiayaan yang diperlukan dalam pembangunan.

\section{Hubungan Antara Utang Luar Negeri dengan Kemiskinan}

Indonesia melakukan hutang luar negeri karena ketidakmampuan sumber pembiayaan dari dalam negeri untuk pembangunan, yaitu tabungan domestik dalam pendanaan bagi pembangunan sepenuhnya. Tabungan domestik dibutuhkan untuk membiayai investasi. Besarnya tabungan yang lebih kecil dibanding dengan rencana kegiatan investasi (saving investment gap) menyebabkan kegiatan pelaksanaan investasi tidak berjalan sesuai rencana. Kesenjangan antara tabungan dan investasi tersebut selanjutnya dapat ditutup dengan masuknya dana dari luar negeri. Salah satu alternatif pembiayaan tersebut adalah melalui utang luar negeri. Utang luar negeri juga berperan dalam mengatasi kemiskinan. Hal ini terjadi karena utang luar negeri memberikan tambahan devisa yang diperlukan untuk membiyai program kemiskinan seperti pembangunan saran dan prasaran infrastruktur, subsidi pendidikan, program langsung tunai dan lain sebagainya.

\section{METODE}

Metode penelitian dampak investasi, proyek dan utang luar negeri Amerika Serikat, Belanda, China dan Jepang terhadap kemiskinan Indonesia tahun 2010-2020 menggunakan metode analisa "Ordinary Least Square" (OLS). OLS digunakan untuk memperoleh analisa untuk dampak variabel independen terhadap variabel dependen. "Metode OLS dipilih karena merupakan salah satu metode sederhana dengan analisis regresi yang kuat dan populer, dengan asumsi-asumsi tertentu" (Gujarati, 2013:102). Data yang digunakan dalam penelitian ini adalah data sekunder dalam bentuk data panel yang sifatnya kuantitatif dalam bentuk angka yang bersumber dari Badan Pusat Statistik, Bank Indonesia dan Kementerian Keuangan.

Menurut Gujarati (2013) kelebihan penggunaan data panel pada penelitian dibandingkan deret waktu dan kerat lintang adalah:

1) estimasi data panel dapat menunjukkan adanya heterogenitas dalam tiap individu;

2) dengan data panel data lebih informatif, lebih bervariasi, mengurangi kolinearitas antar variabel, meningkatkan derajat kebebasan (degree of freedom) dan lebih efisien;

3) studi data panel lebih memuaskan untuk menentukan perubahan dinamis dibandingkan dengan studi berulang dari cross section;

4) data panel lebih mendeteksi dan mengukur efek yang secara sederhana tidak dapat diukur oleh data time series atau cross section;

5) data panel membantu studi untuk menganalisis perilaku lebih kompleks, seperti fenomena skala ekonomi, perubahan teknologi; dan

6) data panel dapat meminimalkan bias yang dihasilkan oleh agregasi individu atau perusahaan karena unit data lebih banyak.

Variabel penelitian ini menggunakan variabel bebas dan variabel terikat. Variabel bebas merupakan variabel yang posisinya mampu berdiri sendiri tanpa terikat dengan variabel lainya. Variabel terikat merupakan variabel yang sangat mudah mendapatkan pengaruh dari variabel lainnya. Variabel bebas pada penelitian ini adalah investasi, proyek dan utang luar negeri Amerika Serikat, Belanda, China dan Jepang tahun 2010-2020. Variabel terikat pada penelitian ini kemiskinan Indonesia tahun 2010-2020. Investasi yang digunakan dalam penelitian ini merupakan realisasi investasi penanaman modal luar negeri dari negara Amerika Serikat, Belanda, China dan Jepang pada tahun 2010-2020, data ini dipilih berdasarkan penamaman investasi terbesar ke Indonesia pada benua yang berbeda. Data proyek yang digunakan dalam penelitian ini merupakan realisasi proyek dari luar negeri yang bekerja sama dengan Indonesia dari negara Amerika Serikat, Belanda, China dan Jepang pada tahun 2010-2020, data ini dipilih berdasarkan proyek terbesar di Indonesia. Utang luar negeri yang digunakan dalam penelitian ini merupakan realisasi utang luar negeri dari negara Amerika Serikat, Belanda, China dan Jepang pada tahun 2010-2020, data ini dipilih berdasarkan penyumbang utang terbesar ke Indonesia sekaligus untuk menganalisis pengaruh utang tersebut terhadap kemiskinan. 


\section{Model Analisis Linear Berganda}

Dalam menggunakan langkah yang menentukan regresi linear berganda diperoleh persamaan:

Kemiskinan $=\alpha+\beta 1 \mathrm{X} 1+\beta 2 \mathrm{X} 2+\beta 3 \mathrm{X} 3+\mathrm{e}$

Dimana:

$\alpha=$ Konstanta

$\beta 1=$ Koefisien X1

$\beta 2=$ Koefisien $X 2$

$\beta 2=$ Koefisien X3

$\mathrm{X} 1=$ Variabel investasi

$\mathrm{X} 2=$ Variabel proyek

$\mathrm{X} 3=$ Variabel utang luar negeri

$\mathrm{e}=$ Error term

\section{Analisis Koefisien Determinasi (R-Square/R2)}

Untuk koefisien determinasi (R2) variabel dependen digunakan untuk mengukur kontribusi setiap variabel independen. Jika (R2) yang diperoleh mendekati 1 (satu), dapat dikatakan untuk meningkatkan model yang menggambarkan hubungan antara variabel independen terhadap variabel dependen. Di sisi lain, (R2) berpengaruh lemah dari variabel independen terhadap variabel dependen, jika R2 ini telah mendekati 0 (nol).

\section{Pengujian Parsial (Uji t)}

Uji t digunakan untuk menunjukan seberapa jauh pengaruh satu variabel independen terhadap variabel dependen dengan menganggap variabel independen lainnya konstan. Perumusan hipotesis pada uji statistik t, yaitu:

Ho: $\beta \mathrm{i}=0$, artinya variabel independen secara parsial tidak berpengaruh signifikan terhadap variabel dependen.

H0: $\beta \mathbf{i} \neq 0$, artinya variabel independen secara parsial berpengaruh signifikan terhadap variabel dependen.

\section{Pengaruh Secara Simultan (Uji F)}

Uji statistik F dasarnya menunjukan apakah semua variabel independen yang dimasukan dalam model mempunyai pengaruh secara bersama-sama atau simultan terhadap variabel dependen, yang merupakan tahapan awal mengidentifikasi model regresi yang diestimasi layak atau tidak. Layak yang di maksudnya adalah model yang diestimasi layak digunakan untuk menjelaskan pengaruh variabel-variabel bebas terhadap variabel terikat. Jika setelah diuji nilai prob. F hitung lebih kecil dari tingkat kesalahan/error (alpha) 0,05 (yang telah ditentukan) maka dapat dikatakan bahwa model regresi yang diestimasi layak, sedangkan apabila nilai prob. F hitung lebih besar dari tingkat kesalahan 0,05 maka dapat dikatakan bahwa model regresi yang diestimasi tidak layak.

\section{Uji Asumsi Klasik}

Uji Normalitas
Keputusan terdistribusi normal tidaknya residual secara sederhana dengan membandingkan nilai Probabilitas JB (Jarque-Bera) hitung dengan tingkat alpha 0,05 (5\%). Apabila Prob. JB hitung lebih besar dari 0,05 maka dapat disimpulkan bahwa residual terdistribusi normal dan sebaliknya, apabila nilainya lebih kecil maka tidak cukup bukti untuk menyatakan bahwa residual terdistribusi normal. Nilai Prob.

\section{Uji Multikolinearitas}

Uji multikolinearitas bertujuan untuk menguji apakah korelasi ditemukan pada model regresi antar setiap variabel independen (independent) dengan kriteria sebagai berikut:

a. Mempunyai angka Tolerance $\leq 0,10$

b. Mempunyai nilai VIF $\geq 10$

\section{Uji Heteroskedastisitas}

Heteroskedastisitas terjadi pada saat residual dan nilai prediksi memiliki korelasi atau pola hubungan. Pola hubungan ini tidak hanya sebatas hubungan yang linier, tetapi dalam pola yang berbeda juga dimungkinkan. Keputusan terjadi atau tidaknya heteroskedastisitas pada model regresi linier adalah dengan melihat Nilai Prob. Fstatistic (F hitung). Apabila nilai Prob. F hitung lebih besar dari tingkat alpha 0,05 (5\%) maka $\mathrm{H} 0$ diterima yang artinya tidak terjadi heteroskedastisitas, sedangkan apabila nilai Prob. F hitung lebih kecil dari dari tingkat alpha $0,05(5 \%)$ maka $\mathrm{H} 0$ ditolak yang artinya terjadi heteroskedastisitas.

\section{HASIL DAN PEMBAHASAN}

Untuk mengetahui metode panel yang akan digunakan diperlukan Uji Chow, Uji Hausman, dan Uji Breusch Pagan Legrange Multiplier, dari hasil penguji hasil Uji Chow diperoleh nilai Cross-section Chi-square sebesar 0,0097<0,05, pada Uji Hausman diperoleh nilai Cross-section random sebesar 0,012<0,005 metode yang digunakan metode Fixed Effect Model. Hasil analisis regresi linier berganda metode OLS dengan data panel, diperoleh suatu bentuk model persamaan dampak investasi, proyek, dan utang luar negeri Amerika Serikat, Belanda, China dan Jepang, terhadap kemiskinan Indonesia tahun 2010-2020.

\section{Uji Asumsi Klasik \\ Uji Normalitas}

Keputusan terdistribusi normal tidaknya residual secara sederhana dengan membandingkan nilai Probabilitas JB (Jarque-Bera) hitung dengan tingkat alpha 0,05 (5\%). Apabila Prob. JB hitung lebih besar dari 0,05 maka dapat disimpulkan bahwa residual terdistribusi normal dan sebaliknya, apabila nilainya lebih kecil maka tidak cukup bukti untuk menyatakan bahwa residual terdistribusi normal. Nilai Prob. JB hitung sebesar $0,170014>0,05$ sehingga dapat 
disimpulkan bahwa residual terdistribusi normal yang artinya asumsi klasik tentang kenormalan telah dipenuhi.

\section{Uji Multikolinearitas}

Hasil uji multikolinieritas, nilai VIF dari ketiga variabel tidak ada yang lebih besar dari 10 maka dapat dikatakan tidak terjadi multikolinieritas pada variabel bebas tersebut. Berdasarkan syarat asumsi klasik regresi linier dengan OLS, maka model regresi linier yang baik adalah yang terbebas dari adanya multikolinieritas. Dengan demikian, model di atas telah terbebas dari adanya multikolinieritas.

\section{Uji Heterokedastisitas}

Keputusan terjadi atau tidaknya heteroskedastisitas pada model regresi linier adalah dengan melihat Nilai Prob. F-statistic ( $F$ hitung). Apabila nilai Prob. F hitung lebih besar dari tingkat alpha 0,05 (5\%) artinya tidak terjadi heteroskedastisitas, sedangkan apabila nilai Prob. F hitung lebih kecil dari dari tingkat alpha $0,05 \quad(5 \%)$ artinya terjadi heteroskedastisitas. Nilai Prob. F hitung sebesar 0,317671 lebih besar dari tingkat alpha 0,05 (5\%) sehingga, berdasarkan uji hipotesis, $\mathrm{H} 0$ diterima yang artinya tidak terjadi heteroskedastisitas.

\section{Koefisien Determinasi (R-Square/ $\boldsymbol{R}^{\mathbf{2}}$ )}

Koefisien determinasi menjelaskan variasi pengaruh variabel-variabel bebas terhadap variabel terikatnya. Berdasarkan hasil regresi didapat nilai koefisien determenasi nilai $\mathrm{R}$-squared sebesar 0,6857 menunjukkan proporsi pengaruh variabel investasi, proyek dan utang luar negeri Amerika Serikat, Belanda, China dan Jepang terhadap kemiskinan Indonesia sebesar $68,57 \%$ artinya investasi, proyek dan utang luar negeri berpengaruh $68,57 \%$ sedangkan sisanya $31,43 \%$ dipengaruhi variabel lain.

\section{Uji Signifikansi Simultan (Uji F)}

Uji statistik F dasarnya menunjukan apakah semua variabel independen yang dimasukan dalam model mempunyai pengaruh secara bersama-sama atau simultan terhadap variabel dependen, yang merupakan tahapan awal mengidentifikasi model regresi yang diestimasi layak atau tidak. Layak yang di maksudnya adalah model yang diestimasi layak digunakan untuk menjelaskan pengaruh variabel-variabel bebas terhadap variabel terikat. Jika setelah diuji nilai prob. F hitung lebih kecil dari tingkat kesalahan/error (alpha) 0,05 (yang telah ditentukan) maka dapat dikatakan bahwa model regresi yang diestimasi layak, sedangkan apabila nilai prob. F hitung lebih besar dari tingkat kesalahan 0,05 maka dapat dikatakan bahwa model regresi yang diestimasi tidak layak.

Hasil uji $\mathrm{F}$ dapat dilihat pada tabel di atas. Nilai prob. F (Statistic) sebesar 0,000429 lebih kecil dari tingkat signifikansi 0,05 sehingga dapat disimpulkan bahwa model regresi yang diestimasi layak digunakan untuk menjelaskan pengaruh investasi, proyek, dan utang luar negeri terhadap variabel terikat kemiskinan.

\section{Pengujian Secara Parsial (Uji t)}

Uji t digunakan untuk menunjukan seberapa jauh pengaruh satu variabel independen terhadap variabel dependen dengan menganggap variabel independen lainnya konstan. Perumusan hipotesis pada uji statistik t, yaitu:

Ho: $\beta \mathrm{i}=0$, artinya variabel independen secara parsial tidak berpengaruh signifikan terhadap variabel dependen.

H0: $\beta \mathrm{i} \neq 0$, artinya variabel independen secara parsial berpengaruh signifikan terhadap variabel dependen.

Nilai prob. $\mathrm{t}$ hitung dari variabel bebas investasi sebesar 0,0003 yang lebih besar dari 0,05 sehingga variabel bebas investasi berpengaruh signifikan terhadap variabel terikat kemiskinan pada alpha 5\% atau dengan kata lain, investasi berpengaruh signifikan terhadap kemiskinan. Sama halnya dengan pengaruh variabel bebas proyek terhadap variabel terikat kemiskinan, karena nilai prob. $\mathrm{t}$ hitung 0,0588 yang lebih besar dari 0,05 sehingga dapat dikatakan bahwa variabel bebas proyek tidak berpengaruh signifikan terhadap variabel terikat Tabungan Nasional, tetapi berpengaruh signifikan terhadap kemiskinan pada signifikansi 0,06. Selanjutnya adalah variabel bebas utang luar negeri sebesar 0,3365 yang berarti tidak berpengaruh signifikan terhadap variabel terikat kemiskinan.

\section{Pembahasan}

Tabel 2. Hasil Analisis Regresi Investasi, Proyek dan Utang Luar Negeri Terhadap Kemiskinan

\begin{tabular}{crrr}
\hline Variable & Coefficient & t-Statistic & Prob. \\
& & & \\
\hline C & 17.64769 & 161.9385 & 0.0000 \\
LN_INVESTASI & -0.032019 & -4.631578 & 0.0000 \\
LN_PROYEK & -0.026395 & -4.658852 & 0.0000 \\
LN_UTANGLUARNEGERI & -0.009008 & -0.732458 & 0.4685 \\
\hline
\end{tabular}

Analisis regresi linear berganda diperoleh hasil sesuai pada tabel diatas:

Kemiskinan $=17,64769-0,032019 \mathrm{X} 1-0,026395 \mathrm{X} 2-$ 0,009008 X3

Hasil persamaan diatas menunjukan investasi, proyek dan utang luar negeri Amerika Serikat, Belanda, China dan Jepang memiliki dampak negatif pada kemiskinan di Indonesia. 
Dampak Investasi Amerika Serikat, Belanda, China dan Jepang Terhadap Kemiskinan Indonesia Tahun 2010-2020

Investasi dapat diartikan sebagai pengeluaran atau perbelanjaan penanam - penanam modal atau perusahaan untuk membeli barang-barang modal dan perlengkapanperlengkapan produksi untuk menambah kemampuan memproduksi barang-barang dan jasa-jasa yang tersedia dalam perekonomian. Dalam penelitian ini investasi berpengaruh negatif terhadap kemiskinan artinya kenaikan investasi akan mengurangi penduduk miskin, setiap kenaikan investasi 1 persen mempengaruhi menurunnya angka kemiskinan sebesar 0,032019 juta penduduk, dari analisis didapatkan nilai probabilitas investasi sebesar 0,0000 artinya investasi berpengaruh signifikan terhadap kemiskinan. Berdasarkan data Badan Pusat Statistik nilai investasi pada tahun 2010-2020 Amerika Serikat sebesar 11.649 juta US\$, Belanda sebesar 7.623 juta sebesar US\$, China sebesar 15.124 US\$, dan Jepang sebesar 27.911 juta US\$ jumlah dari semua sebesar $62.307,3$ juta US\$. Jika diimplikasikan dengan hasil temuan penelitian ini apabila nilai investasi naik 1 persen akan menurunkan kemiskinan sebesar 0,032019 juta penduduk. 1 persen dari $62.307,3$ adalah sebesar 623,07 juta US\$ maka akan menurunkan kemiskinan sebesar 32.019 penduduk. Respon negatif ini menunjukkan bahwa kenaikan investasi akan memberikan respon pada tingkat kemiskinan berupa penurunan jumlah penduduk miskin.

Respon negatif ini dikarenakan semakin besar jumlah investasi yang ditanamkan maka sumber modal untuk menciptakan atau menambah kapasitas produksi dan pendapatan dimasa mendatang pun semakin meningkat, jika pendapatan masyarakat meningkat maka masyarakat yang berada dibawah garis kemiskinan akan berkurang. Sesuai dengan teori yang dikemukakan Sukirno (2006) bahwa kegiatan investasi yang dilakukan oleh masyarakat secara terus menerus akan meningkatkan kegiatan ekonomi dan kesempatan kerja, meningkatkan pendapatan nasional dan meningkatkan taraf kemakmuran masyarakat. Peranan ini bersumber dari tiga fungsi penting dari kegiatan investasi, yakni; (1) investasi merupakan salah satu komponen dari pengeluaran agregat, sehingga kenaikan investasi akan meningkatkan permintaan agregat, pendapatan nasional serta kesempatan kerja (2) pertambahan barang modal sebagai akibat investasi akan menambah kapasitas produksi; (3) investasi akan selalu diikuti oleh perkembangan tekonologi.

Penelitian ini sejalan dengan penelitian yang dilakukan oleh Pateda dkk, (2017) yang menyatakan bahwa investasi berpengaruh negatif terhadap tingkat kemiskinan dengan koefisien sebesar -10,075. Berbeda dengan penelitian yang dilakukan oleh Waruwu (2016) yang menyatakan bahwa investasi tidak berpengaruh terhadap tingkat kemiskinan di Indonesia. Kegiatan investasi sebaiknya dilakukan untuk program pengentasan kemiskinan seperti membangun perusahaan yang menyerap tenaga kerja banyak/padat karya, investasi tidak hanya bersifat fisik tetapi non fisik seperti investasi sumber daya manusia dibidang pendidikan dan pelatihan. Investasi dibidang pendidikan dan pelatihan akan mampu meningkatkan kualitas sumber daya manusia dan mendorong keterampilan. Peningkatan pengetahuan dan keahlian akan mendorong produktifitas seseorang, sehingga perusahan akan memberikan gaji yang lebih tinggi bagi tenaga kerja yang produktif. Ini akan meningkatkan kesejahteraan masyarakat dan menolong mereka keluar dari lingkaran kemiskinan. Investasi swasta juga berpengaruh negatif terhadap kemiskinan, swasta dalam menjalankan produksi/operasional perusahaanya mendapatkan suntikan dana investasi akan meningkat produksinya dan menyerap tenaga kerja baru, menurut hasil penelitian Hasan (2020) temuan menunjukkan bahwa inflasi berpengaruh positif terhadap pengangguran dan kemiskinan, dan tingkat investasi swasta berpengaruh negatif terhadap pengangguran dan kemiskinan.

\section{Dampak Proyek Amerika Serikat, Belanda, China dan Jepang Terhadap Kemiskinan Indonesia Tahun 2010- 2020}

Kegiatan proyek pembangunan merupakan suatu kegiatan sementara yang berlangsung dalam jangka waktu tertentu, dengan alokasi sumber daya tertentu untuk menghasilkan produk yang kriteria mutunya telah disusun dengan jelas, proyek ini diharapkan memberikan keuntungan. Pada periode penelitian ini proyek berpengaruh negatif terhadap kemiskinan artinya kenaikan proyek akan mengurangi penduduk miskin, setiap kenaikan nilai proyek 1 persen mempengaruhi menurunnya angka kemiskinan sebesar 0,026395 juta penduduk, dari analisis didapatkan nilai probabilitas proyek sebesar 0,0000 artinya proyek berpengaruh signifikan terhadap kemiskinan. Data Badan Pusat Statistik nilai proyek pada tahun 2010-2020 Amerika Serikat sebesar 7.702,49 juta US\$, Belanda sebesar $14.817,78$ juta sebesar US\$, China sebesar 20.916,85 US\$, dan Jepang sebesar 37.229,37 juta US\$ jumlah dari semua sebesar 80.666,49 juta US\$. Jika diimplikasikan dengan hasil temuan penelitian ini apabila nilai proyek naik 1 persen akan menurunkan kemiskinan sebesar 0,026395 juta penduduk, 1 persen dari $80.666,49$ juta US\$ adalah sebesar 806,66 juta US\$ maka akan menurunkan kemiskinan sebesar 26.395 penduduk.

Hasil analisis pengaruh negatif proyek terhadap kemiskinan ini menunjukkan bahwa kenaikan proyek akan memberikan respon pada tingkat kemiskinan berupa penurunan jumlah penduduk miskin. Pengaruh negatif ini dikarenakan semakin besar jumlah proyek yang dilakukan maka sarana dan prasarana infrastruktur akan meningkat dan melancarkan proses distribusi 
barang dan jasa sehingga menciptakan kapasitas produksi yang tinggi dan pendapatan dimasa mendatang pun semakin meningkat, jika pendapatan masyarakat meningkat maka masyarakat yang berada dibawah garis kemiskinan akan berkurang. Menurut Solow-Swan (Mankiw, 2003) campur tangan pemerintah tidak perlu terlalu banyak dalam mempengaruhi pasar. Namun pemerintah hanya sebatas campur tangan dalam kebijakan fiskal dan kebijakan moneter. Dalam teori ini menjelaskan tingkat pertumbuhan berasal dari tiga sumber, yaitu akumulasi modal (investasi), bertambahnya penawaran tenaga kerja, dan peningkatan teknologi. Penjelasan dari teori neo-klasik ini menunjukkan bahwa untuk menciptakan suatu pertumbuhan yang bagus maka diperlukan suatu tingkat saving yang tinggi dan seluruh keuntungan pengusaha diinvestasikan kembali. Investasi ini salah satunya dalam bentuk proyek harus dirancang dengan cermat untuk mengarahkan proyek tersebut pada sektor ekonomi produktif dan harus model padat karya, ini akan menciptakan lapangan pekerjaan untuk masyarakat lokal dan mengembangkan keterampilan lokal sehingga merangsang penurunan tingkat kemiskinan di daerah tersebut.

Data dari Japan International Coorporation Agency (2018) Beberapa proyek kerjasama yang telah dilakukan Jepang dan negara dalam objek penelitian ini, pembangunan fasilitas tenaga pembangkit listrik 11.000 megawatt, Per tahun 2016, total kapasitas pembangkit tenaga listrik yang dibangun oleh ODA Jepang sebesar 3.948 Megawatt. Bila ditambah dengan proyek IPP (Independent Power Producer), kapasitasnya akan mencapai 10.963 Megawatt. Ini setara dengan 20\% dari total kapasitas listrik di Indonesia. Sektor Pertanian dan ketahanan pangan, pemerintah Indonesia bekerjasama dengan negara Jepang dalam hal peningkatan produktivitas pertanian dengan perluasan area irigasi seluas 370.000 hektar, Jepang dan negara-negara mitra telah melaksanakan pembangunan lebih dari 80 fasilitas irigasi melalui Pinjaman ODA, dan merealisasikan perluasan area irigasi sekitar 370.000 hektar. Hal ini berkontribusi terhadap produksi beras sekitar 2 juta ton/tahun, sehingga juga memberikan dampak yang besar dari sudut pandang ketahanan pangan.

Bidang transportasi proyek kerjasama Indonesia, China dan Jepang telah merencanakan kereta bawah tanah pertama Indonesia, untuk meringankan kemacetan lalu lintas yang ada pada kota-kota besar di Indonesia, meningkatkan mobilitas barang dan jasa supaya pertumbuhan ekonomi meningkat, dan memenuhi kebutuhan transportasi penduduk seiring kenaikan jumlah penduduk, serta untuk mendorong penggunaan transportasi umum, Jepang telah mendukung modernisasi sarana transportasi kereta api di wilayah metropolitan Jakarta sejak tahun 1980-an (sepanjang 126 $\mathrm{km}$, atau $55 \%$ dari $230 \mathrm{~km}$ ) serta pembangunan kereta bawah tanah (MRT: Mass Rapid Transit) pertama di Indonesia.

Pembangunan jalan tol, pembangunan wilayah Pulau Sumatera merupakan salah satu faktor penunjang yang mendorong pertumbuhan ekonomi Indonesia dan memunculkan sumber perekonomian baru selain di Pulau Jawa. Hal ini didukung oleh jalur lintas Sumatera, jalur utara-selatan yang panjang totalnya $2.500 \mathrm{~km}$, yang mana sekitar $60 \%$ dari jalan tersebut dibangun melalui kerjasama dengan Jepang.

Proyek pembangunan yang baik harus memperhatikan dampak terhadap lingkungan, proyek pembangunan tidak hanya mencapai tujuan mengurangi kemiskinan, meningkatkan indeks pembangunan manusia, dan meningkatkan harapan hidup, tetapi proyek juga harus menjaga kelestarian lingkungan, mencegah degradasi lingkungan, dan mencegah polusi udara. Menurut penelitian Akinlo (2021) yang berjudul The moderating effect of foreign direct investment on environmental degradation-poverty reduction nexus: evidence from sub-Saharan African countries. Hasil penelitian ini peningkatan investasi asing berpengaruh terdahap degradasi lingkungan pada negara sub-gurun Sahara Afrika.

\section{Dampak Utang Luar Negeri Amerika Serikat, Belanda, China dan Jepang Terhadap Kemiskinan Indonesia Tahun 2010-2020}

Pembiayaan melalui utang luar negeri merupakan pembiayaan pembangunan yang dikembalikan dengan bunganya, melalui utang yang diperoleh pemerintah dari pemberian pinjaman luar negeri yang diikat oleh suatu perjanjian pinjaman dan tidak berbentuk surat berharga negara, yang harus dibayar kembali dengan persyaratan tertentu. Pada penelitian ini utang luar negeri berpengaruh negatif terhadap kemiskinan, dari analisis didapatkan nilai probabilitas utang luar negeri sebesar 0,4685 artinya utang luar negeri tidak berpengaruh signifikan terhadap kemiskinan. Dana utang luar negeri antara lain pembangunan infrastruktur yang tidak banyak berdampak langsung pada perekonomian nasional, alihalih menciptakan lapangan kerjaan bagi rakyat dalam negeri, sebagian proyek padat karya justru banyak melibatkan tenaga asing seperti dari negara Singapura, Korea Selatan, China, dan India. Menurut data Izin Memperkerjakan Tenaga Kerja Asing (IMTA) Kementerian Ketenagakerjaan (2018) jumlah tenaga kerja asing di Indonesia mencapai 95.335 pekerja. Tenaga kerja asing di Indonesia paling banyak adalah pekerja dari China sebanyak 32.000 pekerja, banyaknya tenaga kerja asing dari China tersebut karena meningkatnya aliran dana asing/utang dari negara tersebut. Jumlah tenaga kerja asing Korea Selatan berada di Indonesia merupakan yang terbesar ke-2 setelah China, tenaga kerja asing berasal dari Korea Selatan sebanyak 12.490 pekerja. Disusul pekerja dari negara 
India sebesar 7.000 pekerja, tenaga kerja asing dari Amerika Serikat sebesar 4.000 pekerja, tenaga kerja asing dari Singapura sebesar 3.500 pekerja dan dari negara lainya.

Atmadja (2000) Dalam jangka pendek, utang luar negeri sangat membantu pemerintah Indonesia dalam upaya menutup defisit anggaran pendapatan dan belanja negara, akibat pembiayaan pengeluaran rutin dan pengeluaran pembangunan yang cukup besar. Dengan demikian, laju pertumbuhan ekonomi dapat dipacu sesuai dengan target yang telah ditetapkan sebelumnya. Tetapi dalam jangka panjang, ternyata utang luar negeri pemerintah tersebut dapat menimbulkan berbagai persoalan ekonomi di Indonesia seperti pembayaran bunga semakin besar, inflasi, dan nilai tukar rupiah.

Pada masa krisis ekonomi, utang luar negeri Indonesia, termasuk utang luar negeri pemerintah, telah meningkat drastis dalam hitungan rupiah. Sehingga, menyebabkan pemerintah Indonesia harus menambah utang luar negeri yang baru untuk membayar utang luar negeri yang lama yang telah jatuh tempo. Akumulasi utang luar negeri dan bunganya tersebut akan dibayar melalui APBN RI dengan cara mencicilnya pada tiap tahun anggaran. Hal ini menyebabkan berkurangnya kemakmuran dan kesejahteraan rakyat pada masa mendatang, sehingga jelas akan membebani masyarakat, khususnya para wajib pajak di Indonesia.

Utang luar negeri memiliki batas aman supaya tidak menjadi bumerang bagi negara, batas aman rasio utang luar negeri terhadap PDB (Produk Domestik Bruto) adalah 60 persen. Berdasarkan data Direktorat Jenderal Pengelolaan Pembiayaan dan Resiko Kementerian Keuangan, pergerakan utang adalah sebesar Rp794 miliar atau 29\% terhadap PDB pada Orde Lama, lalu era Orde Baru mencapai US\$68,7 miliar atau setara Rp551,4 triliun dengan rasio utang sebesar 57,7\% terhadap PDB, dan era Reformasi yakni sejak tahun 1998 hingga sekarang sebesar US\$340,543 miliar atau sekitar Rp3.825,79 triliun atau 28,1\% terhadap PDB. Di era Refromasi, rasio utang pemerintah sempat mencapai tertinggi sepanjang sejarah yakni $88,7 \%$ terhadap PDB pada tahun 2000 dengan nominal sebesar Rp1.232,8 triliun. Namun setelah itu tren rasio utang pemerintah terus mengalami penurunan hingga sekarang ini tidak mencapai separuh dari batas aman yang ditetapkan dalam UU Keuangan Negara

\section{SIMPULAN}

Berdasarkan hasil analisis penelitian dan pembahasan, maka kesimpulan yang diperoleh adalah investasi Amerika Serikat, Belanda, China dan Jepang berpengaruh negatif dan signifikan terhadap kemiskinan Indonesia, pada setiap peningkatan 1 persen investasi berdampak pada menurunya kemiskinan sebesar 0,032019 juta penduduk dengan asumsi ceteris paribus. Proyek Amerika Serikat, Belanda, China dan Jepang berpengaruh negatif dan signifikan terhadap kemiskinan Indonesia, pada setiap peningkatan 1 persen proyek berdampak pada menurunya kemiskinan sebesar 0,026395 juta penduduk dengan asumsi ceteris paribus. Utang luar negeri Amerika Serikat, Belanda, China dan Jepang berpengaruh negatif tidak signifikan hal ini dikarenakan utang luar negeri belum optimal dalam pengentasan kemiskinan. dalam jangka panjang, ternyata utang luar negeri pemerintah dapat menimbulkan berbagai persoalan ekonomi di Indonesia seperti pembayaran bunga semakin besar, pekerja asing masuk Indonesia karena dana utang yang masuk dari negara asal, inflasi, dan nilai tukar rupiah.

Beberapa saran sehubungan dengan hasil analisis penelitian ini adalah pemerintah Indonesia sebaiknya terus meningkatkan investasi dan proyek dengan negara mitra, beberapa langkah yang telah dilakukan pemerintah terus diperbaiki seperti membangun kawasan industri, kawasan ekonomi khusus dan kawasan strategis pariwisata nasional. Membangun kawasan industri memiliki beberapa permasalahan diantaranya pembebasan lahan/tersedianya tanah untuk dibangun kawasan industri, sebaiknya pemerintah melakukan komunikasi yang baik dengan masyarakat sekitar supaya tidak terjadi konflik dengan pemilik tanah warga sekitar kawasan industri. Penanganan dampak lingkungan akibat adanya investasi juga harus diperhatikan oleh pemerintah.

Utang luar negeri sebaiknya dikelola dengan baik oleh pemrintah dan Bank Indonesia, utang luar negeri sebaiknya digunakan dan lebih diprioritaskan untuk meningkatkan kesejahteraan rakyat Indonesia.

Kebijakan pemerintah dalam rangka menstabilkan nilai tukar, inflasi dan kondisi keamanan negara terus dipertahankan ini bertujuan untuk mempertahankan para investor. Pertumbuhan ekonomi yang baik dan infrastruktur terus dibangun diharapkan dapat mendukung kegiatan usaha sehingga dapat melirik investor asing untuk menanamkan investasinya di Indonesia. Untuk itu, Pemerintah Indonesia diharapkan meningkatkan iklim investasi memalui kebijakan menjaga stabilitas ekonomi, politik, keamanan dalam negeri dan memperbaiki sarana dan prasarana infrastruktur.

Pemerintah diharapkan membenahi iklim investasi supaya perusahaan-perusahaan Amerika Serikat, Belanda, China dan Jepang makin banyak lagi menanamkan modalnya. Semua regulasi baik di pemerintah pusat maupun pemerintah daerah yang menghambat investasi harus dipangkas. Pemerintah sudah mengesahkan UU Omnibus Law dalam rangka menciptakan iklim investasi yang baik di Indonesia, konsep Omnibus Law ini akan menggabungkan aturan terkait perizinan bisnis diberbagai kementerian/lembaga menjadi satu undang-undang yang akan dijadikan payung hukum baru, konsep Omnibus Law ini sebaiknya 
menguntungkan bagi semua pihak, baik dari pihak tenaga kerja, pihak pengusaha dan pihak pemerintah.

Menjalin hubungan/kerjasama dengan negara lain seperti Uni Emirat Arab, Mesir, Afrika Selatan, Korea dan negara lainya yang memiliki potensi investasi besar. Pemerintah telah menandatangi nota kesepahaman sebesar 22,8 miliar US\$ dengan Uni Emirat Arab, Kerja sama tersebut untuk pengembangan energi berkelanjutan, membagi visi mengenai pertumbuhan hijau sebagai cara untuk mentransformasi ketahanan energi menjadi energi berkelanjutan serta mendukung nilai asli Islam dalam mendorong toleransi serta beberapa lainnya. Sebaiknya pemerintah menjalankan kerjasama ini dengan baik sehingga pengusaha negara mitra bisa bertahan/menambah investasinya di Indonesia.

Proyek-proyek yang telah disepakati dengan negara mitra diharapkan dapat menyerap tenaga kerja rakyat Indonesia, sehingga rakyat Indonesia mendapatkan pendapatan, hidup sejahtera dan akhirnya dapat mengurangi angka kemiskinan.

\section{DAFTAR PUSTAKA}

Atmadja, Adwin Surya. (2000). Utang Luar Negeri Pemerintah Indonesia : Perkembangan dan Dampaknya. Jurnal Akuntansi \& Keuangan. Vol. 2 No. 1.

Gujarati, Damodar. (2013), "Ekonometri Dasar". Terjemahan: Sumarno Zain, Jakarta: Erlangga.

Japan International Coorperation Agency. (2018). Publikasi Pembangunan Indonesia dan Kerjasama Jepang: Membangun Masa Depan Berdasarkan Kepercayaan.

Jhingan, M.L. 2000. Ekonomi Pembangunan dan Perencanaan. Jakarta: PT Raja Drafindo Persada.

Kementerian Ketenagakerjaan. (2018). Fact SheetKetenagakerjaan Asing\&Hubungan Indutrial.

Mankiw, Gregory N. 2003. Teori Makro Ekonomi Terjemahan. Jakarta: PT. Gramedia Pustaka Utama.

Monicaria Tarigan. (2021). Analisis Pengaruh Investasi, Tenaga Kerja, Dan Pertumbuhan Ekonomi Terhadap Tingkat Kemiskinan Di Indonesia. Tesis. Universitas Sumatera Utara.

Nance Hasan dan Muammil Sun'an. (2020). The Effect of Private Inflation and Investment on Unemployment and Poverty in North Maluku Province. Jurnal of International Conference Proceendings. Vol.3.No. 3

Rizky Pratama, Paulus Kindangen Een N. Walewangko. (2017). Analisis Pengaruh Investasi, Tenaga Kerja Dan Tingkat Pendidikan Terhadap Pertumbuhan Ekonomi Dan Dampaknya Terhadap Kemiskinan Di Provinsi Sulawesi Utara. Jurnal Pembangunan Ekonomi dan Keuangan Daerah. Vol. 18 No. 7.
Seri, Jefry. A.Waruwu. (2016). Analisis Pengaruh Pertumbuhan Ekonomi Pengangguran Belanja Pemerintah dan Investasi Terhadap Tingkat Kemiskinan di Indonesia, Yogyakarta: Jurnal Ilmu Ekomomi Universitas Sanata Dharma. Vol. 2 No. 3.

Shopia Ayu dan Sri Sulamiyati. (2018). Pengaruh Foreign Direct Invesment, Ekspor, Dan Utang Luar Negeri Terhadap Pertumbuhan Ekonomi ASEAN (Studi Pada Produk Domestik Bruto Indonesia, Malaysia, Dan Thailand Periode Tahun 2007 - 2016). Jurnal Administrasi Bisnis. Vol. 61 No. 3.

Sukirno, Sadono. (2006). Makro Ekonomi Teori Pengantar. Jakarta: PT.Raja Grafindo Persada.

Susilowati, Dwi dan Muhammad Sri Wahyudi Suliswanto. 2015. Pertumbuhan Ekonomi, Indeks Pembangunan Manusia, Utang Luar Negeri dan Kemiskinan (Kajian Teoritis di Indonesia). Jurnal Ekonomika-Bisnis Volume 6 No.1, 89-106.

Rizky Yulita Sutikno, Dhebby Ch. Rotinsulu, dan Steeva Y. L. Tumangkeng (2019). Pengaruh Upah Minimum Dan Investasi Terhadap Kemiskinan Di Provinsi Sulawesi Utara. Jurnal Berkala Ilmiah Efisiensi. Vol. 19. No.1.

Taiwo Akinlo dan James Temitope D. (2021). The moderating effect of foreign direct investment on environmental degradation-poverty reduction nexus: evidence from sub-Saharan African countries. Journal Enviroment, Development, and Sustainably. Vol. 2 No. 1.

Todaro, Michael P., dan Smith, Stephen C. (2006). Pembangunan Ekonomi/ Edisi Kesembilan, Jilid 1 (Alih Bahasa: Haris Munandar dan Puji A.L.). Jakarta: Penerbit Erlangga.

Todaro, Michael. et al. (2011). Pembangunan Ekonomi. Jakarta: Erlangga.

Yolanda P, Vecky A.J dan Tri O. (2017). Pengaruh Investasi, Pertumbuhan Ekonomi dan Pengeluaran Pemerintah Terhadap Tingkat Kemiskinan di Gorontalo. Jurnal Ilmu Ekonomi. Vol. 3 No. 7. 